\title{
Effect of Various Additives on the Preservation of Carnation Mottle Virus
}

\author{
Fumiyoshi Fukumoto* and Hiroshi Tochinara*
}

\begin{abstract}
Freezing for a duration of one hour followed by thawing did not cause any detectable change in infectivity and sucrose density gradient centrifugation profiles of a purified preparation of carnation mottle virus (CaMV) suspended in $10 \mathrm{mM}$ potassium phosphate buffer (P. B.), $\mathrm{pH}$ 7.0. Infectivity of purified CaMV decreased considerably after 38-51 months of storage under frozen conditions at $-20 \mathrm{C}$. However, the infectivity was maintained at a high level for 38-51 months by the addition of peptone or glycerol, etc. At $-70 \mathrm{C}$, the virus remained highly infective for a long period without any additives. The infectivity of the purified CaMV decreased markedly when freeze-dried at $\mathrm{pH}$ 5.5-8.5 and subsequently suspended in P. B. The virions of these preparations became swollen at $\mathrm{pH}$ higher than 7.5 and aggregated at $\mathrm{pH}$ 5.5-6.0. But, the changes in the conformation of CaMV virions due to freezedrying were prevented by the addition of lysine. The protective effect of additives during preservation of freeze-dried preparations was assessed at $65 \mathrm{C}$. The viral preparation freezedried in P. B. lost its infectivity within one day, but the preparation supplemented with lysine remained highly infective even after 7 days. The preservation conditions for CaMV were similar to those for southern bean mosaic virus which is physicochemically similar to CaMV.
\end{abstract}

(Received February 26, 1986)

Key words : carnation mottle virus, preservation, swelling.

\section{Introduction}

Carnation mottle virus (CaMV) is an isometric virus of about $28 \mathrm{~nm}$ in diameter, and consists of an RNA genome of molecular weight (MW) $1.4 \times 10^{6}$ and coat protein of MW $38,000^{3)}$. Hull ${ }^{4}$ proposed a new group for carnation mottle virus, but this group has not yet been approved by International Committee on Taxnnomy of Viruses. CaMV is isolated as a single sedimenting component like southern bean mosaic virus (SBMV), and the virions are stabilized by divalent cations and a pH dependent bond but significantly by RNA-protein interactions ${ }^{5,6)}$. The properties of CaMV virions are similar to those of SBMV except that RNA-protein interactions are important in maintaining the virion conformation in SBMV.

By freeze-drying, the virions of purified SBMV became swollen and their infectivity decreased markedly, but the deformation of the virions could be significantly prevented by the addition of lysine ${ }^{2}$. Thus the conditions for preservation of CaMV under frozen or freeze-dried conditions were investigated, comparing with those previously reported

* National Agriculture Research Center, Tsukuba Science City, Yatabe, Ibaraki 305, Japan 農業 研究センター 
for SBMV').

\section{Materials and Methods}

CaMV isolated from a carnation plants (Dianthus caryophyllus L.) ${ }^{10}$ was propagated in carnation plants (cultivar Enfant de Nice) and purified by almost the same procedure used for $\mathrm{SBMV}^{2}$. For determining preservation efficiency under freezing or freezedrying, the preparations of purified CaMV were treated by the same procedure employed for SBMV2). Twelve half leaves of Chenopodium amaranticolor were used for quantitative assays of infectivity. The preparations preserved were diluted to a 2.5$10 \mathrm{ng} / \mathrm{ml}$ concentration, and were inoculated on C. amaranticolor to determine the infectivity, according to the method routinely used for SBMV. The preserved preparations were also examined by electron microscopy and sucrose density gradient centrifugations. The degree of virus aggregation was also determined as previously reported ${ }^{2}$.

\section{Results}

\section{Freezing and thawing}

Purified CaMV preparations adjusted at a concentration of $50 \mu \mathrm{g} / \mathrm{ml}$ in $10 \mathrm{mM}$ potassium phosphate buffer (K-P. B.), $\mathrm{pH} 7.0$, frozen at $-20 \mathrm{C}$ or $-70 \mathrm{C}$ for one hour and then thawed in water at $35-37 \mathrm{C}$, retained $94 \%$ and $92 \%$ of the original infectivity, respectively. These preparations showed no alteration in sucrose density gradient centrifugation profile and in virion structures as detected by electron microscopy.

\section{Preservation under frozen conditions}

The preparations of purified CaMV, which had been treated with various additives, were preserved at $-20 \mathrm{C}$ or $-70 \mathrm{C}$. At $-20 \mathrm{C}$, the infectivity of the preparations decreased considerably after 38-51 months of storage. However, the addition of $0.5 \%$ peptone or $3 \%(\mathrm{v} / \mathrm{v})$ glycerol to the preparation afforded maximum protection, maintaining a high level of infectivity for 38-51 months. Purified CaMV preparations were also protected by the addition of $2.5 \%$ sucrose, $0.5 \%$ lysine or $0.5 \% \mathrm{Na-glutamate.} \mathrm{In} \mathrm{con-}$ trast, $2.5 \%$ glucose, $2.5 \%$ sorbitol or $3 \%(\mathrm{v} / \mathrm{v})$ dimethyl sulfoxide were not effective. When stored at $-70 \mathrm{C}$, purified $\mathrm{CaMV}$ preparations remained highly infective for 38 51 months without any additives (Fig. 1).

\section{Freeze-drying : effect of $\mathrm{pH}$ of the medium}

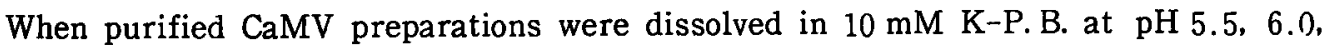
$6.5,7.0,7.5,8.0$ and 8.5 to give a concentration of $1 \mathrm{mg} / \mathrm{ml}$, and freeze-dried, the infectivity decreased to $13 \%, 21 \%, 37 \%, 22 \%, 12 \%, 5 \%$ and $2 \%$ of original value, respectively. Analysis by sucrose density gradient centrifugation showed that sedimentation profiles more or less changed depending upon $\mathrm{pH}$ of the buffer used for freeze-drying. The peak of CaMV virions did not shift extensively at near neutrality, but bacame practically negligible at $\mathrm{pH} 5.5$ and shifted to slowly sedimenting boundaries at $\mathrm{pH} 8.0$ or 8.5 (Fig. 2). The absorbance values at $260 \mathrm{~nm}$ of the supernatants from low-speed centrifugation of the preparations freeze-dried at $\mathrm{pH} 5.5$ and 6.0 , were $15 \%$ and $44 \%$ 


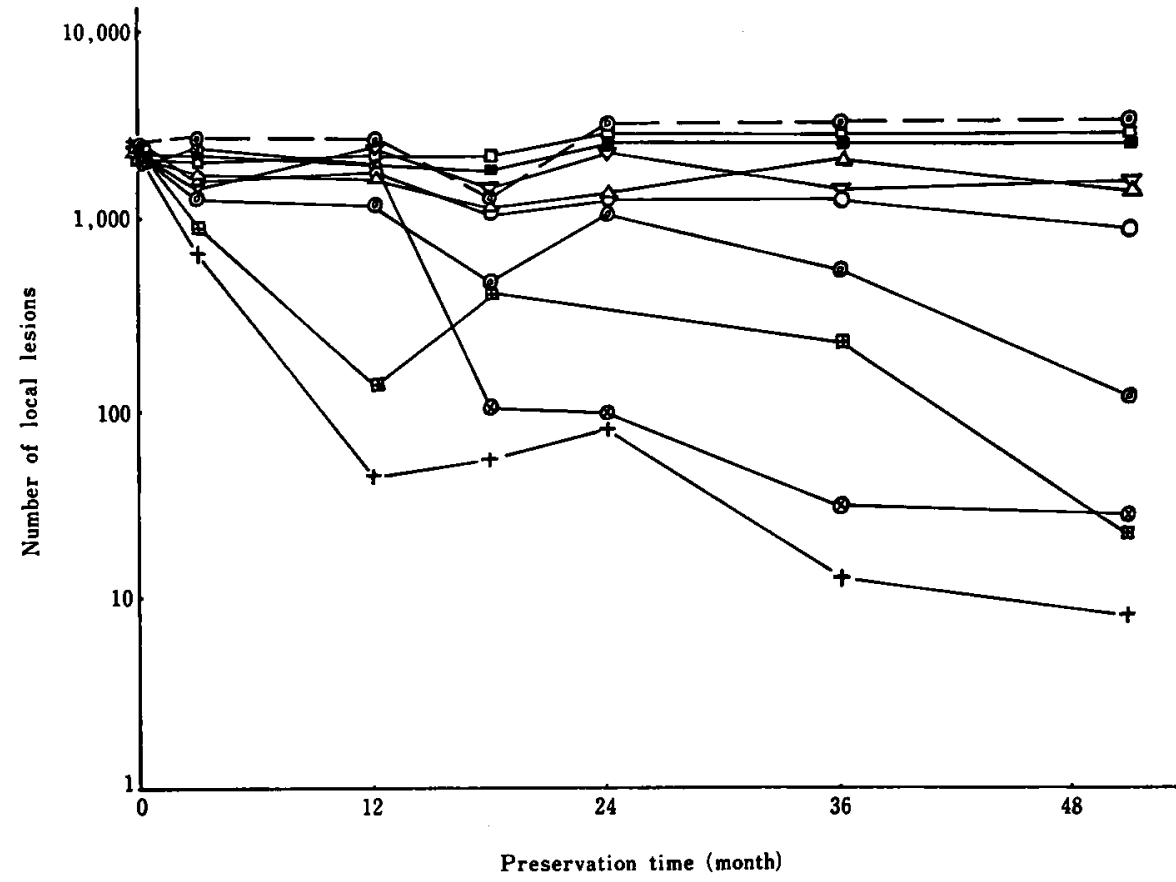

Fig. 1. Effect of various additives on infectivity of purified CaMV preparations preserved under frozen conditions. Number of local lesions: total number of local lesions in eight half leaves of Chenopodium amaranticolor. — : $-20 \mathrm{C},--:-70 \mathrm{C}$. $\mathrm{O}: 2.5 \%$ sucrose, 1 : $: 2.5 \%$ glucose, $+: 2.5 \%$ sorbitol. $\nabla: 0.5 \%$ lysine, $\square: 0.5 \%$ peptone, $\triangle: 0.5 \%$ sodium glutamate, $\square$ : $3 \%(\mathrm{v} / \mathrm{v})$ glycerol, $\otimes: 3 \%(\mathrm{v} / \mathrm{v})$ dimethyl sulfoxide, (๑) : no additives.

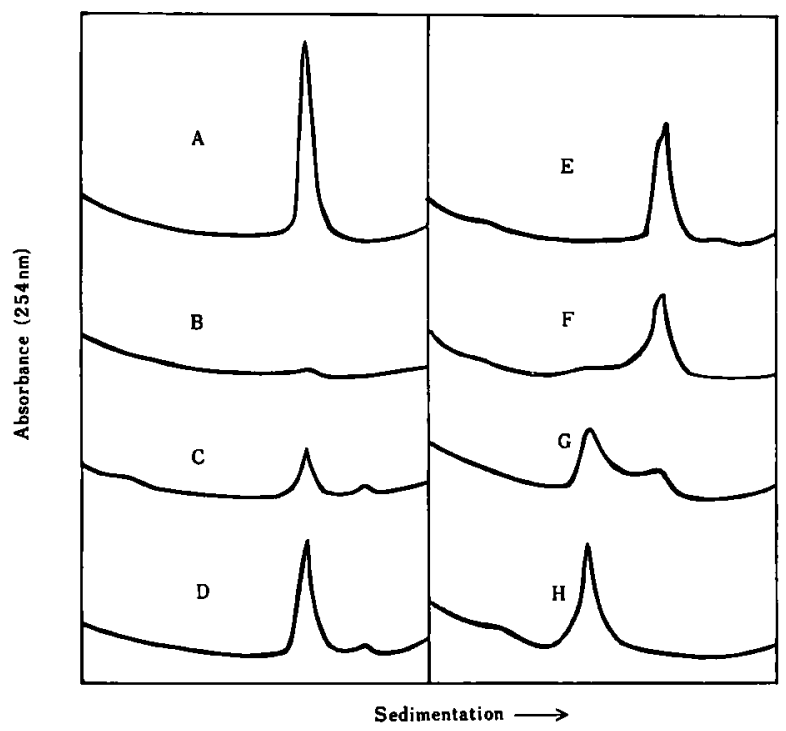

Fig. 2. Sucrose density gradient sedimentation profiles of purified CaMV at various $\mathrm{pH}$ after freeze-drying. (A): non-freeze-dried CaMV, (B-H): freeze-dried CaMV at various $\mathrm{pH},(\mathrm{B}): \mathrm{pH} 5.5,(\mathrm{C}): \mathrm{pH} 6.0$, (D): $\mathrm{pH}$ 6.5, (E): $\mathrm{pH} 7.0,(\mathrm{~F}): \mathrm{pH} 7.5,(\mathrm{G}): \mathrm{pH} 8.0,(\mathrm{H}): \mathrm{pH}$ 8.5. 
of the untreated control, respectively. The supernatants of the preparations freeze-dried at $\mathrm{pH} 6.5-8.5$ retained $76 \%$ to $100 \%$, suggesting that freeze-dried virions had not been aggregated in this $\mathrm{pH}$ range.

\section{Freeze-drying : effect of molarity of medium}

The effect of buffer concentration on the viral inactivation due to freeze-drying was examined with K-P. B., $\mathrm{pH} \mathrm{7.0.} \mathrm{The} \mathrm{infectivity} \mathrm{of} \mathrm{the} \mathrm{preparations} \mathrm{freeze-dried} \mathrm{in}$ water or in $10 \mathrm{mM}, 25 \mathrm{mM}, 0.1 \mathrm{M}$ and $0.2 \mathrm{M} \mathrm{K}-\mathrm{P}$. B. decreased to $0.1 \%, 56 \%, 49 \%$, $25 \%$, and $19 \%$ of non-freeze-dried control, respectively. When $10 \mathrm{mM}, 25 \mathrm{mM}, 0.1 \mathrm{M}$ or $0.2 \mathrm{M} \mathrm{NaCl}$ was added to the purified CaMV preparations in $10 \mathrm{mM} \mathrm{K}-\mathrm{P}$. B., values of infectivity were $53 \%, 20 \%, 22 \%$ and $17 \%$ of the untreated control, respectively. These values were similar to those observed with corresponding concentrations of $K-P$. B. In sucrose density gradient centrifugation profiles, CaMV virion bands became broader in $25 \mathrm{mM}, 0.1 \mathrm{M}$ and $0.2 \mathrm{M} \mathrm{K}-\mathrm{P}$. B. The alteration of virions due to freeze-drying became more clear as the molarity of the medium increased. The alterations were more extensive in the preparations added with $\mathrm{NaCl}$.

The supernatants from low-speed centrifugation of the purified CaMV preparations

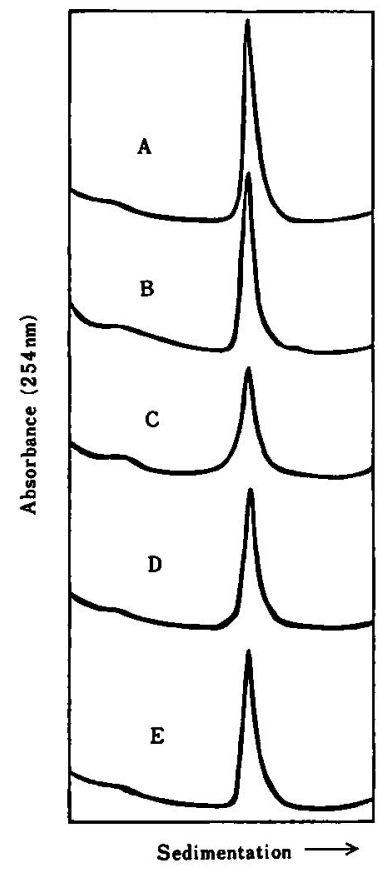

Fig. 3. Sucrose density gradient sedimentation profiles of purified preparations of CaMV treated with additives after freezing or freeze-drying. (A) : untreated CaMV, (B): CaMV after freezing, (C) $-(E)$ : CaMV after freeze-drying, (C): no additives, (D) : $0.5 \%$ lysine, (E) : $0.5 \%$ sodium glutamate.
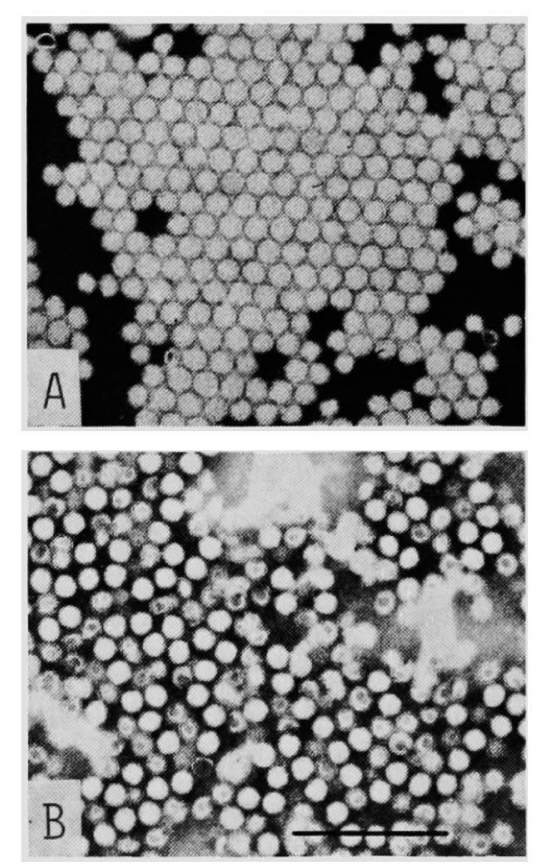

Fig. 4. Electron micrograghs of purified CaMV after freeze-drying. (A): non-freezedried CaMV, (B): freeze-dried CaMV. Bar represents $200 \mathrm{~nm}$. 
freeze-dried in $10 \mathrm{mM}-0.2 \mathrm{M} \mathrm{K}-\mathrm{P}$. B. or in $10 \mathrm{mM} \mathrm{NaCl}$ retained $84-94 \%$ of absorbancy of the untreated control, suggesting that no aggregation had occurred in these preparations. However, CaMV dissolved in water or $25 \mathrm{mM}, 0.1 \mathrm{M}$ or $0.2 \mathrm{M} \mathrm{NaCl}$ solutions before freeze-drying, became cloudy, and the amounts of virions in the supernatants after low-speed centrifugation decreased to $4 \%, 67 \%, 54 \%$ and $45 \%$ of the untreated control, respectively.

\section{Freeze-drying: effect of various additives}

Effect of various additives on preservation efficiency was examined with the purified CaMV dissolved in $10 \mathrm{mM} \mathrm{K-P.} \mathrm{B.,} \mathrm{pH} \mathrm{7.0,} \mathrm{at} \mathrm{a} \mathrm{concentration} \mathrm{of} 50 \mu \mathrm{g} / \mathrm{ml}$. Infectivities of purified CaMV preparations and those added with $1 \%$ dextran $\mathrm{T}-10$ decreased by freeze-drying to $11 \%$ and $14 \%$ of the original titer, respectively. However, the addition of $0.5 \% \mathrm{Na}$-glutamate, $1 \%$ glucose, $0.5 \% \mathrm{Na}$-asparaginate, $1 \%$ sucrose, $0.5 \%$ lysine, 0.5 96 cysteine, $1 \%$ lactose, $1 \%$ inositol or $0.5 \%$ peptone before freeze-drying afforded a remarkable protection, giving $87 \%, 85 \%, 74 \%, 70 \%, 61 \%, 57 \%, 56 \%, 52 \%$ and $50 \%$, respectively, of the original infectivity. Infectivities of the preparations supplemented with $0.5 \%$ glycine, $1 \%$ Ca-lactobionate, $1 \%$ soluble starch or $1 \%$ sorbitol, were $38-44$ $\%$ of the original infectivity.

Sucrose density gradient centrifugation indicated that the addition of glucose, Calactobionate, sorbitol, inositol, sucrose, lactose, lysine, glycine, Na-glutamate, Na-asparaginate, peptone or cysteine was effective in keeping virions intact (Fig. 3). Soluble starch gave a negligible protection, and dextran $\mathrm{T}-10$ had no effect. In specimens stained with $1 \%$ phosphotungstic acid ( $\mathrm{pH}$ 6.5), a large number of virions freeze-dried in $10 \mathrm{mM} \mathrm{K}$-P. B., pH 7.0, were penetrated by the stain (Fig. 4).

\section{Freeze-drying: protective efficiency as affected by virus concentration}

The viral inactivation by freeze-drying was examined with CaMV preparations of various concentrations. The infectivities of preparations freeze-dried at concentrations of $1,10,50$ and $100 \mu \mathrm{g} / \mathrm{ml}$ in $10 \mathrm{mM} \mathrm{K}-\mathrm{P}$. B., $\mathrm{pH} 7.0$, were $18 \%, 19 \%, 37 \%$ and $69 \%$ of those freeze-dried at $1 \mathrm{mg} / \mathrm{ml}$, indicating higher concentrations were preferable for minimizing damages from freeze-drying.

\section{Freeze-drying : effect of various additives as assessed at high temperature}

To confirm the protective effects of various additives, the freeze-dried preparations were preserved at $65 \mathrm{C}$. The freeze-dried preparation of purified CaMV at a concentration of $50 \mu \mathrm{g} / \mathrm{ml}$ in $10 \mathrm{mM} \mathrm{K}-\mathrm{P}$. B., $\mathrm{pH} \mathrm{7.0,} \mathrm{lost} \mathrm{most} \mathrm{of} \mathrm{its} \mathrm{infectivity} \mathrm{within} \mathrm{one} \mathrm{day,}$ and the addition of $1 \%$ sorbitol, $1 \%$ inositol, $1 \%$ dextran T-10, $1 \%$ lactose, $1 \% \mathrm{Ca}$-lactobionate, $1 \%$ soluble starch, $0.5 \%$ glycine or $0.5 \%$ cysteine did not protect the preparation from inactivation. The protective effect of various additives was in the order of $0.5 \%$ lysine $>0.5 \%$ peptone $\geqq 1 \%$ sucrose $>0.5 \% \mathrm{Na}$-glutamate and $0.5 \% \mathrm{Na}$-asparaginate, and the preparations supplemented with lysine remained a highly infective even after 7 days of storage at this temperature (Fig. 5). The test of protective effect of lysine at concentrations ranging from $0.05 \%$ to $3 \%$ showed that $1.5 \%$ or $3 \%$ lysine protected the preparation to the same extent as with $0.5 \%$ lysine. The protective effect of $0.05 \%$ or $0.1 \%$ lysine was inferior to those observed at $0.5 \%$ to $3 \%$. The protective effects were determined of preparations supplemented with $0.5 \%$ lysine, $0.5 \%$ peptone or $1 \%$ sucrose, singly or in combination. Infectivities of preparations supple- 


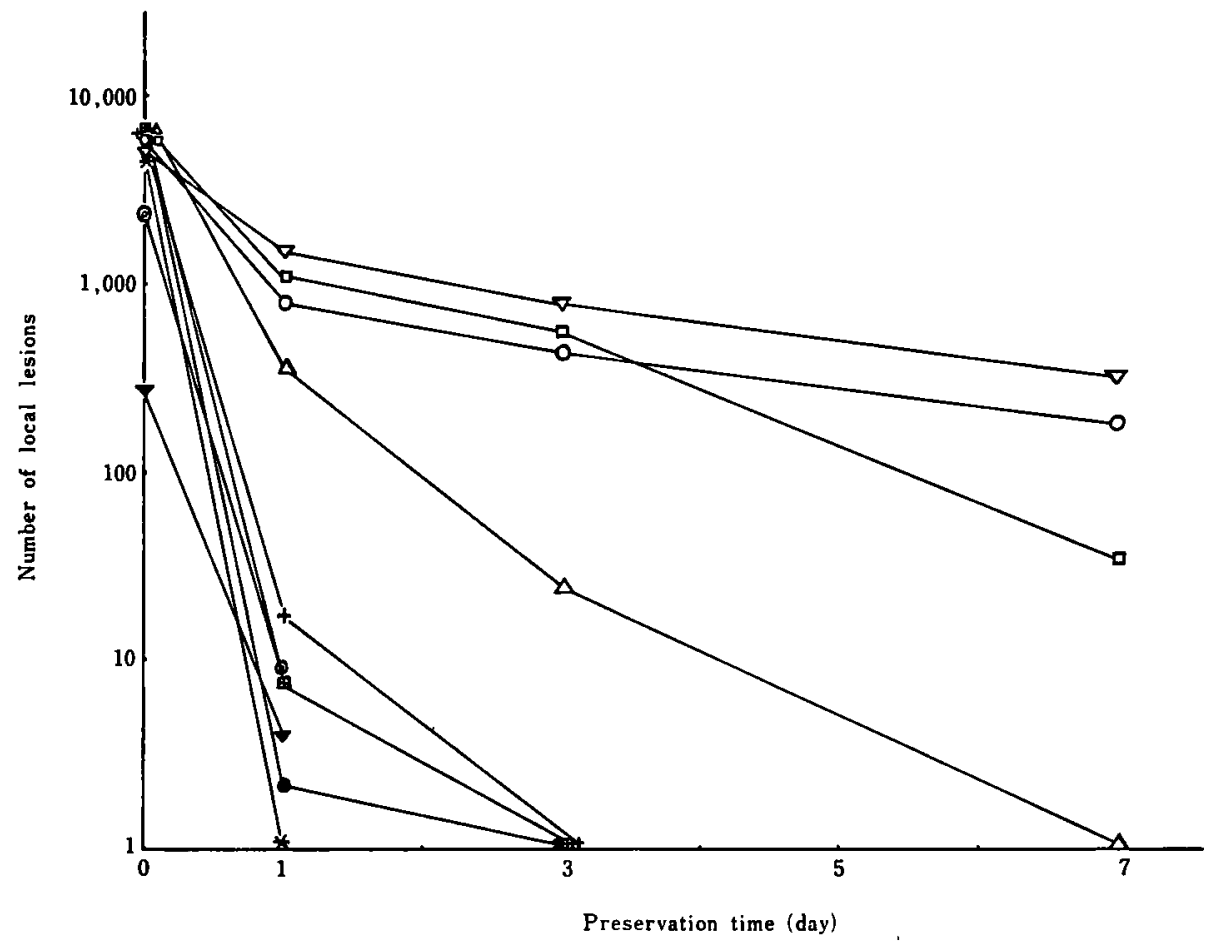

Fig. 5. Effect of various additives on infectivity of purified CaMV preparations preserved at $65 \mathrm{C}$ under freeze-dried conditions. Number of local lesions: total number of local lesions in eight half leaves of Chenopodium amaranticolor. $\bigcirc: 1 \%$ sucrose, $\rightarrow: 1 \%$ glucose, $: 1 \%$ inositol, + : $1 \%$ sorbitol, $\nabla: 1 \%$ dextran $\mathrm{T}-10, \nabla: 0.5 \%$ lysine, $*: 0.5 \%$ glycine, $\square: 0.5 \%$ peptone, $\triangle: 0.5 \%$ sodium glutamate, (@) no additives.

mented with lysine + peptone, lysine + sucrose or lysine + peptone + sucrose were almost similar to those supplemented with lysine alone. The protective effect of peptone + sucrose was also similar to that of peptone alone. Thus, there seems to be no synergistic effect among these additives.

\section{Discussion}

Tochihara et al. ${ }^{10)}$ reported that the infectivity of purified CaMV preparations decreased markedly during storoge for 37 months at $-20 \mathrm{C}$. The results in this paper confirmed the infectivity loss during preservation. Peptone and glycerol effective for the preservation of SBMV which is similar to CaMV in physicochemical properties ${ }^{5,6}$, were also effective protectants for the long-term preservation of $\mathrm{CaMV}$ at $-20 \mathrm{C}$. Al. though the addition of glucose, sorbitol or DMSO was effective to SBMV, none of these was protected CaMV, indicating that there are some differences in stabilizing forces between these two viruses.

The differences are also evident in $\mathrm{pH}$ dependent conformation and infectivity changes during freeze-drying. Freeze-drying of purified CaMV caused virion swelling at $\mathrm{pHs}$ above 7.5 and severe aggregation at $\mathrm{pH}$ 5.5-6.0, while SBMV swelled at $\mathrm{pH}$ 5.5-8.5 
without aggregation. The CaMV preparations freeze-dried in $10 \mathrm{mM}$ P. B., $\mathrm{pH} 5.5-7.0$ or in $10 \mathrm{mM}-0.2 \mathrm{M}$ P. B. at $\mathrm{pH} 7.0$ were highly infective level comparing with those of SBMV under the same condition. On the contrary, the infectivity of CaMV at $\mathrm{pH} \mathrm{8.0-}$ 8.5 was lower than those of SBMV. These results indicate that there are some differences between CaMV and SBMV in terms of virion stability.

Hull $^{5,6)}$ suggested that CaMV is rather similar to SBMV in physicochemical properties. The present results partially support his conclusion. The morphology and infectivity of both viruses were preserved well by the addition of lysine, as was clearly demonstrated by preservation at $65 \mathrm{C}$. However, sucrose and peptone which did not protect SBMV protected CaMV virions from the damage caused by freeze-drying or occurred during preservation process.

In spite of these differences, the suitable conditions for preservation of these two viruses were similar, comparing with other viruses such as Nepoviruses or Comoviruses $^{1)}$, which dissociate into RNA and coat protein by freeze-drying. The similarity observed of CaMV and SBMV in freeze-drying preservation suggests that the viruses belonging to tabacco necrosis virus group ${ }^{81}$ and tombusvirus group ${ }^{7,91}$ which are similar in virion properties to CaMV and SBMV may probably be preserved well under the conditions devised for these two viruses.

\section{Literature cited}

1. Fukumoto, F. and Tochihara, H. (1984). Ann. Phytopath. Soc. Japan 50:158-165.

2. Fukumoto, F. and Tochihara, H. (1985). Ibid. $51: 413-420$.

3. Hollings, M. and Stone, O. M. (1970). C.M.I./A.A.B. Descriptions of Plant Viruses No. 7.

4. Hull, R. (1977). J. gen. Virol. $36: 289-295$.

5. Hull, R. (1977). Virology $79: 50-57$.

6. Hull, R. (1977). Ibid. $79: 58-66$.

7. Krüse, J., Krüse, K. M., Witz, J., Chauvin, C. and Jacrot, B. (1982). J. Mol. Biol. 162 : 393-417.

8. McCarthy, D., Bleichmann, S. and Thorne, J. (1980). J. gen Virol. $46: 391-404$.

9. Robinson, I. K. and Harrison, S. C. (1982). Nature $297: 563-568$.

10. Tochihara, H., Idei, T., Yabuki, S. and Fukumoto, F. (1975). Ann. Phytopath. Soc. Japan 41 : 390-399.

和 文 摘 要

福本文良・榞原比呂志：カーネーション斑紋ウイルスの保存に及ばす各種添加物の影響

カーネーション斑紋ウイルス (CaMV) について簡便で長期間安定な保存方法を確立するため, 各種添加物 を加えて東結求上び凍結乾燥保存を行い以下の結果を得た。10mM りん酸緅衡液 $\mathrm{pH} 7.0$ に照濁した純化ウ イルスでは凍結 1 時間の処理によってウイルス活性に変化が認められなかったが，-20C で凍結保存した標 品はしだいに活性が低下した。しかし，ペプトングリセリンなどを添加した唀品では長期間高い活性が維持 された。 $-70 \mathrm{C}$ 保存ては無添加の標品であ高い活性が維持された。 pH 5.5-8.5 ウイルス液を涷結乾燥処理

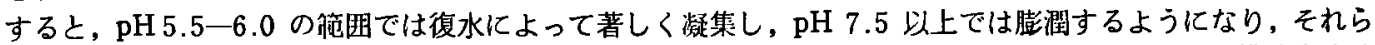
の活性は著しく低下した。しかし、リジンを添加した標品では顕著な保蓝勃果が認められ，粒子の㯕造変化は 少なくなり，活性も简く維持された。無添加で凍結乾燥した標品を $65 \mathrm{C}$ で保存すると，1 日で活性がほとん ど失われたが、リジンを源加した標品には７日後でも高い活性が認められた。CaMV の保存条件は，粒子の 物理化学的性質が類似しているインゲンマメ南部モザイクウイルスのそれに類似していた。 